\title{
Small isn't beautiful either
}

AT the beginning of January 1976, one pound sterling would buy 2.02 US dollars. Last week you could get only $\$ 1.66$ for a pound; at one stage as little as $\$ 1.63$. This depreciation of nearly $20 \%$ in sterling is making for grim news almost everywhere in Britain; the laboratories of British universities will feel the pinch, for the Science Research Council (SRC) is almost certainly facing an acute financial crisis.

Within the past year the SRC, in common with many organisations dispensing government money, has had to accept cash limits on its activities, that is to say, it has been given a firm sum of money above which it may not commit itself. The SRC has also, of course, been told by the Advisory Board of Research Councils (ABRC) to trim its spending over the next five years by $10 \%$ in real terms. To achieve this, the so-called big sciences have been told that many major national projects cannot go ahead, and international facilities such as CERN, Institut LaueLangevin and the European Space Agency have accordingly increased in importance. Subscriptions to these internationai organisations amount to about $30 \%$ of SRC's budget, and go up every time the pound goes down.

So now, in order to fulfil its international obligations, the SRC is looking for $£ 6$ million more than it had budgeted for-with cash limits in operation to prevent it from simply going to the Treasury and asking for the difference. In fact the Treasury is prepared to sympathise to the tune of $£ 2$ million, so the SRC is left either to cut $£ 4$ million off domestic expenditure, to sweet-talk CERN into letting us pay less, or (the most likely) some combination of these two.

What can be done on the domestic scene? The SRC has relatively few options open, in that much of its money is committed for long-term projects already half-done. Vulnerable spots are therefore new grant proposals and new research studentships. The new crop of research students is barely large enough to satisfy demand; even some candidates with first-class degrees have not yet been placed, and eight hundred candidates with upper-second degrees are going to be disappointed. On the research grants side the scene is even grimmer. At the last round of grant-giving there were significant numbers of applicants who failed even though their application had been rated in the top category. This had never happened before. One of the options that the SRC is bound to be considering is that the next round of proposals (there are three a year) is simply dropped altogether.

In the somewhat longer run, SRC may have to get down to the serious business of making some of its own staff redundant. It employs nearly 3,000 in six laboratories and headquarters. With generous redundancy terms to meet, the council is unlikely to benefit in the short term from such action, but it might be encouraged by the contents of a forthcoming Confederation of British Industry document 'The Road to Recovery' which, according to The Economist, will suggest that industry could create a million new jobs, into which a hundred wellqualified SRC employees could surely fit.

The irony of the SRC's present crisis is that if grant giving is seriously curtailed it will be the 'small sciences' which will suffer, in order to keep the big sciences going-hardly ABRC's intention when it looked to more use of international facilities by Britain's big scientists.

\section{More on Argentina}

CONCERN about the plight of scientists in Argentina has grown steadily since we published a letter from Italian academics on the subject (July 22). It has become increasingly clear that a country whose scientific skills have been widely acknowledged and respected is in the greatest danger of abandoning its intellectual traditions and becoming a scientific backwater. The number of academics and workers in research institutes who have lost their jobs is growing all the time, and some fairly detailed documentation is emerging.

Inevitably, when left- and right-wing extremists are at loggerheads, some of those dismissed or detained will have had a history of political activity, and thus will be vulnerable to charges of using their position for political rather than academic purposes. But many others, relatively apolitical, seem to have been caught in the crossfire. When military politicians such as General Vilas can say that "until we can cleanse the teaching area, and professors are all of Christian thought and ideology we will not achieve the triumph we seek in our struggle against the revolutionary left", there is little hope that anything resembling academic freedom can survive.
Even the Atomic Energy Commission does not seem to have escaped the general purge. At least eight employees are known to have been arrested: Carlos Calle, Dr Domi and his wife Maria Dipace, Pedro Landeyro, Antonio Misetich (who worked for a time at MIT's National Magnet Laboratory), Santiago Morazzo, Pedro Victoria. We know a little about their situation because $\mathrm{Dr}$ Virgilo Victoria-Troncoso, brother of Maximo Pedro Victoria and an ophthalmologist at the University of Ghent, Belgium, has recently been to see his brother (who has worked overseas, for example at Lawrence Radiation Laboratory) in prison in Argentina. He reports that the scientists, physicians and psychiatrists he saw in the Villa Devoto prison in Buenos Aires were kept in 35 cells, five to a one-bedded cell with dimensions $3 \mathrm{~m}$ by $2.40 \mathrm{~m}$. They have been without meat for months. They have no legal representation, no charges have been brought against them and it is impossible to bring a writ of habeas corpus. "My brother", says Dr Troncosco, "has been beaten up and he has lost teeth. The situation is worse than in a novel of Kafka".

It is difficult to see why nuclear scientists have been imprisoned except that there was a technical difference of opinion some time ago in which Dr Victoria, amongst others, was involved. It concerned the choice of fuel for a new reactor, and Dr Victoria and colleagues favoured natural uranium whereas a group of military scientists favoured enriched uranium. The former view prevailed and it may be that the military, which has in large part taken over leading civilian positions, is determined to settle an old score.

What can scientists do in the face of the widespread breakdown of all the conventional respect for the intellectual life and academic freedom? Amnesty International (53 Theobalds Rd, London WC1) can provide extensive lists of missing Argentinian academics who could be written to-preferably in Spanish, because the authorities are unlikely to pass on anything in English. Dr Victoria's address, for instance, is now 649, Unidad 2, Sierra Chica, Province of Buenos Aires, Argentina. A letter to Excelentisimo General Jorge Rafael Videla, Presidente de la Republica Argentina, Casa Rosada, Buenos Aires, Argentina couldn't do much harm. And maybe it is going to be necessary to try and find academic places outside Argentina for these victims of extremist politics. 